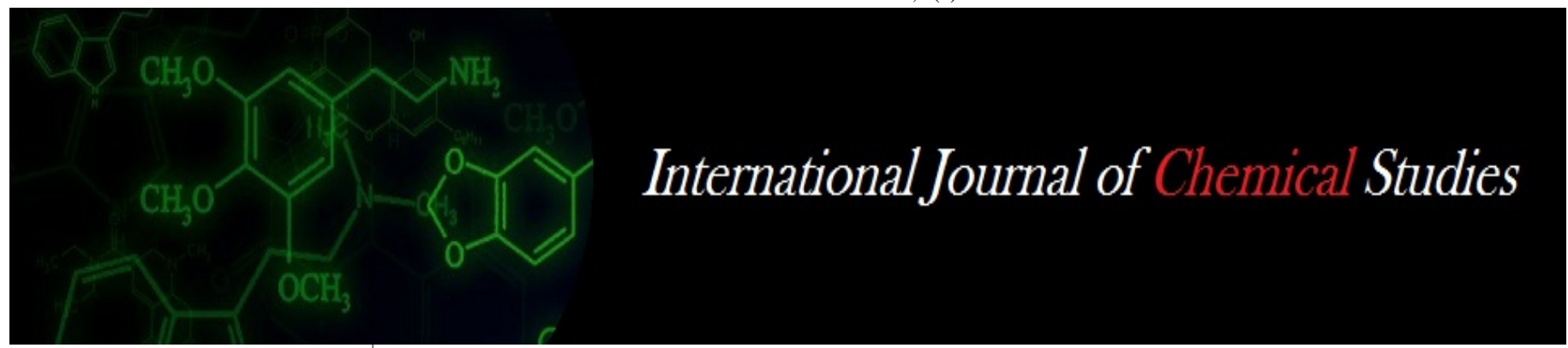

P-ISSN: 2349-8528

E-ISSN: 2321-4902

www.chemijournal.com

IJCS 2020; 8(6): 1320-1328

(C) 2020 IJCS

Received: 11-09-2020

Accepted: 16-10-2020

Priyanshu Sharma

M.Sc. Ag. Horticulture,

Floriculture and Landscaping,

Department of Horticulture,

School of Agriculture, Lovely

Professional University

Jalanadhar, Phagwara, Punjab, India

Neelam Thakur

Assistant Professor Floriculture and Landscaping, Department of Horticulture, School of

Agriculture, Lovely Professional

University Jalanadhar,

Phagwara, Punjab, India

\section{Effect of pulsing and storage methods for extending vase life of cut flowers}

\author{
Priyanshu Sharma and Neelam Thakur
}

DOI: https://doi.org/10.22271/chemi.2020.v8.i6s.10943

\begin{abstract}
Flower cultivation is one the most popular strategy in the sector of horticulture. In recent years, the international trade of cut flowers has expanded and would be expected to increase further with promotion and application in various industries. Because of the fascinating nature of the cut flowers, they are loved by the people around the world but the less vase life of cut flowers creates problem in transporting to the other countries. So it is necessary to overcome from this problem as it is most important to meet the satisfaction of consumer. Pulse treatment with sucrose has been found a best preservative solution to extend the vase life of cut flowers. However, various pre harvest and post harvest factors can also affect the vase of cut flowers. So, by providing optimum condition to the cut flowers, vase life can be extended.
\end{abstract}

Keywords: Cut flowers, vase life, pulsing, STS, sucrose

\section{Introduction}

Floriculture is the branch of horticulture that deals with the cultivation of flowering and ornamental plants to use as cut flower, loose flower, pot plants and to sale various industries to make perfumes cosmetics, bouquet etc. Because of the wide genetic diversity, floriculture industry provides self employment good earnings to the small and marginal farmers, hence it is the sunshine industry of India. The world's growth rate per annual of the industry is 8 to $10 \%$ (Census of India, 2001). However, on large scale, more than 120 countries are active in floriculture. Around the world, India is the second largest producer of floriculture, moreover there are top 10 exporters around the world viz. Netherlands, Colombia, Ecuador, Kenya, Ethiopia, Italy etc. Though, there are various types of flowers present in the world, among all those there are cut flowers. Cut flowers are those flowers which are harvested with stem. The various cut flowers are rose, carnation, chrysanthemum, gerbera, tuberose, bird of paradise, freesia, tuberose, lilium, dahlia, gladiolus etc. Since many years, postharvest quality of cut flowers engaged many researchers and worker's attention as cut flowers have short vase life. So they are cultivated near to the marketing centers. Cut flowers are very fascinating so they attract people towards their beauty. As they are loved by most of the people around the world, so there is a need of distributing flowers from one country to another but they could not be distributed because of the short vase life. To provide the people, a better flower quality, the vase life of cut flowers should be extended (Zeltzer et al., 2001) ${ }^{[76]}$.

\section{Pre-harvest factors (before harvest)}

There are so many other factors that affect the vase life of cut flowers and the factors are low storage temperatures (Celikel \& Reid, 2002; Bunya-atichart et al. 2004) ${ }^{[16]}$ and high relative humidity (Reid \& Jiang, 2012). To promote water uptake (Eason 2002; Asrar 2012) ${ }^{[20]}$ and to control microorganisms (Macnish et al., 2008) ${ }^{[43]}$, various preservatives of flowers are applied. Likewise, to minimize the effect of ethylene (Celikel et al., 2002; Serek et al., 2006) ${ }^{[16]}$ and to induce and improve opening of flower (Eason et al. 2004). To overcome from this problem, it was found that the use of modified atmosphere packaging can increase the vase life of cut flowers (Reid 2001; Reid \& Jiang 2012) as this technique was done in various other species other than flower crops. This technique gave significant results (extending the vase life) in various cut flower crops like in rose (De Pascale et al., 2005), lily (Wu et al., 2013) and carnation (Bishop et al. 2007). Modifies atmosphere packaging is a modification based system

\section{Priyanshu Sharma}

M.Sc. Ag. Horticulture,

Floriculture and Landscaping, Department of Horticulture,

School of Agriculture, Lovely Professional University

Jalanadhar, Phagwara, Punjab, India 
on environment within in a package and this is done to improve the vase life of stored products. The common practice done for fresh cut flowers by minimizing the amount oxygen, maximizing the carbon dioxide to minimize the metabolic activity (Rennie \& Tavoularis, 2009). Despite this, less oxygen results in the less production of ethylene and hence inhibit the ripening of fresh products (Sandhya, 2010). The inner atmosphere of the packages could be artificially modified by filling the mixture of gas before closing or without an active response, by sealing packages under normal conditions of air and this will depend on the rate of respiration of the product and the package permeability (Montanez et al., 2010). Hence, once the balance between the respiration rate of product and the package permeability has been attained, the vase of the product would obviously maximizes.

\subsection{Favorable environmental conditions}

As through the phenotypic alterations, the vase life potential of cut flowers is affected by various growth conditions. During growth, a constant relative humidity and minimum vapor pressure lead to the minimum responsiveness of stomata and hence, there is excessive loss in water which leads to the short vase life of cut flowers like rose (Fanourakis et.al, 2013, 2015). And this type of conditions which are no favorable are often found in winters in greenhouse when, to prevent the loss of heat, vents are kept close. Likewise, because of the medium and high water potential which is used as an effective method for high yields in hydroponics and the cur flowers that are grown in such conditions usually shows premature wilting.

Despite this, there are various other pre-harvest (before harvest) environmental factors which shortens the vase life of cut flowers and those factors are temperature, light, humidity, ethylene, carbon dioxide etc.

- Light: as like photosynthesis, there are various physiological processes which determine the content of carbohydrate in flowers. Flowers contain relatively higher quantity of carbohydrates such as sugars, as it lasts longer in the vase. Moreover hight light intensity and low light intensity behaves differently as high light intensity causes scorching of flower bud and foliage, dropping of leaves and petals senescence. On the other hand, low light intensity causes petal discoloration and bent neck and stem bending in rose and gerbera (Halevy and Mayak, 1979) ${ }^{[27] .}$

- Temperature: The requirement of temperature varies with the crop and this requirement varies even with day and night. For instance, the day temperature required by rose is $20-25^{\circ} \mathrm{C}$ and the night temperature is $16^{\circ} \mathrm{C}$ and this day and night temperature is believed to be ideal for the growth and production of flower. Although, low night temperatures are considered best as low respiration at low temperature minimizes the sugar utilization and thus improves the carbohydrate accumulation in the petals whereas high temperature leads to the poor post-harvest life. It must be keep in mind that temperature should not be very low as this causes freezing injury to buds.

- Humidity: As like temperature, the level of humidity also varies with crop. For instance, between 60-65\% relative humidity is required by rose crop. If this level is high, then various fungal and bacterial diseases may occur whereas less than optimum humidity causes browning of edges of leaf and thin leaves. However, post harvest life of various cultivars of rose is affected by high air humidity (i.e. 90\%) and a 24hour photoperiod.
However, it was stated that the reduction is responsible to maximize the loss water loss from leaves and due to failure in closing of stomata, loss of water from leaves also enhances (Mortenseon and Fjeld, 1998).

- Ethylene: The cut flower quality and longevity based on the ambient atmosphere composition. The most adverse effects are caused by ethylene. In carnation, gynoecium is the part where ethylene is firstly produced.

- Carbon dioxide: The content of carbon dioxide in atmosphere is very less (Kumar et al., 2002) ${ }^{\text {[37]. The }}$ enrichment of carbon dioxide in greenhouse is believed best as it maximizes the vase life and also improves the quality.

\subsection{Varietal differentiation}

Based on different reasons viz. water uptake, flower diameter, stem lignifications, senescence behavior and vase life etc., the varieties of cut flowers are varied.

\subsection{Fertilizer and management of diseases and pests}

The quality of the cut flowers and any other commodity should be good and for that precautions must be taken from the nursery stage to minimize the infection occur by bacteria, fungi and insects. Because the damage that they cause, results in the wilting and ethylene production (Nowak and Rudnicki, 1990) ${ }^{[49]}$ that leads to the senescence of petals and fall of leaves.

Although in increasing growth and flower yield, fertilizers play a crucial role. As a component of integrated nutrient management, organic manures are also important to develop more yield of crop and to maintain the soil health. Adequate amount of plant nutrients should be apply at adequate time to minimize different nutrient losses that maximizes the efficiency of nutrient use. However, for enhancing the quality and yield of flower crops, biofertilizers along with nutrients plays a crucial role (Janakiram et al., 2017).

\section{Post harvest factors (after harvest)}

As like pre-harvest factors, there are different post-harvest factors that affect the vase life of cut flowers viz. light, temperature, humidity, ethylene sensitivity, water quality, ventilation, packaging etc.

\subsection{Water uptake}

The post harvest life of flowers depend on some factors viz. uptake and transport of water, loss of water and the flower tissue potential to hold its water. When the absorption of water is enhanced by the transpiration, wilting and rarity of water occurs. Consequently, scarcity of water can also be occur due to the break down of column of water in the vessels of stem by inhibition to flow of water and embolism of water. So uptake of water can be improve by water acidification and by adding some wet agent and flower food to the holding solutions (Kushal et al., 2013) [64]. However, the salt concentration should be optimum such as in gladiolus, $700 \mathrm{ppm}$ concentration is harmful as it decreases the vase life whereas in carnation and chrysanthemum, even 200ppm concentration is harmful (Waters, 1968) ${ }^{[71]}$.

\subsection{Water quality}

The quality of water is defines as the value of hardness of $\mathrm{pH}$ and EC, phytotoxic elements and microorganism content that cause vascular occlusion and hence reduces the post harvest life of cut flowers. As like other factors, the quality of water is also a main factors which affect the longevity. Vase life of 
flowers minimizes if the vase solution include saline water (Phavaputanan and Ketsa, 1988, 1990).

If we talk about ions then hard water containing $\mathrm{Ca}^{++}$and $\mathrm{Mg}^{++}$ions affect less as compared to the soft water containing sodium ions. Flourine causes injury to most of the flowers even at small concentration (i.e. 1ppm). On the other hand due to low $\mathrm{pH}$ value or low content of $\mathrm{CaCO}_{3}$ and $\mathrm{Ca}\left(\mathrm{HCO}_{3}\right)_{2}$, as the longevity of rose can be extended upto five days (Brecheisen et al., 1995). Despite this, the vase life of cut flower can be extended by tap water due to the presence of translocation of cations and anions (Rajan, 1993). And the blockage can be reduced by minimizes the content of water by boiling.

\subsection{Temperature}

The crucial thing which determine the vase life of cut flowers is the temperature. At high temperature, the flower bud opening and the senescence rate speeds up. On the other hand, low temperature slows down the rate of respiration and less amount of ethylene is produced by flowers which leads to the less rate of multiplication of microorganism. Some flowers such as tropical flowers are very sensitive to low temperature so these are stored at high temperature (i.e. $8-15^{\circ} \mathrm{C}$ ). Although, flower is kept in low temperature for immature bud opening and the low temperature would be as low as $0^{\circ} \mathrm{C}$ for carnations, 1 and $4^{\circ} \mathrm{C}$ for rose and gladiolus, $8^{\circ} \mathrm{C}$ for strelitzia and for anthurium and tropical and subtropical orchid is $10^{\circ} \mathrm{C}$. Depending upon the categories, pre cooling temperature of various cut flowers should be maintained at optimum level, to remove field heat, prohibit the rapid loss of water and minimize the sensitivity of ethylene to flower. It was stated that flower opening is hastened by high temperature but this also minimizes the vase life of cut flowers (Ichimura et al., 1999) ${ }^{[30]}$. Sucrose content and the sucrose synthetase activity in petals have been found to be lower in rose. In chrysanthemum, it was found that the rate of rehydration in cut flowers become accelerated with low air temperature (Van Meeteren, 1989).

\subsection{Ethylene}

Ethylene has primary role in the in ethylene sensitive flowers. During flower development and senescence in various flowers organs, the concentration of ABA and ethylene varies (Jone, 2004; Ferrante et al., 2006) ${ }^{[23]}$. Depending upon the ethylene involvement, the flowers has been categorize into two systems viz. ethylene sensitive and ethylene insensitive. However, ethylene involvement during senescence of flowers and its importance has been observed in various plant species like Dianthus, delphinium, Lathyrus, Consolida and Ranunculus (van Doorn, 2001; Hoeberichts et al., 2007; van Doorn and weltering, 2008; Ichimura et al., 2009; Shahri et al., 2011). In these species, ethylene exposure speed up the senescence. Though there are some ethylene action blockers of lowers viz. Silver thiosulphate (STS), 2,5- norbonadiene (NBD) or 1-methyle cyclopropene (1- MCP), significantly maximizes the longevity of flowers. Moreover in transgenic and wild carnation, it was found that genetic modification of insensitivity of ethylene is more effective as compared to the other chemicals treatments which are used to extend the vase life of cut flowers. However in most of the ethylene sensitive flowers, production of ethylene is increased by pollination and speed up senescence (Kato et al., 2002). It is observed in carnation that pollinated stigma produces ethylene and transferred by stigma and ovary to petals where it stimulates biosynthetic genes of ethylene and regulates the ethylene production in petals (Have and Woltering, 1997). It was stated that in daffodils, flowers respond to ethylene just after the pollination or before that its response is minimum (Hunter et al., 2002) ${ }^{[29]}$.

It was found that the xylem occlusion (i.e. blockage of xylem vessel by air and microorganism) is the major problem behind the deterioration of cut flowers. To extend the vase life, better treatments should be given. Many studies has been done to find the best treatment to extend the vase life of cut flowers and an important germicide 8-HQS was used in the floral industry (Nowak and Rudnicki, 1990) ${ }^{[49]}$. As it has some special properties like it act as an antibacterial agent (Kesta et al., 1995) and can maximize the uptake of water (Reddy et al., 1995) [53]. However, the reason behind the most disadvantageous effects are occurred by the ethylene i.e. leaf yellowing into flower/ leaf, chancy opening and premature

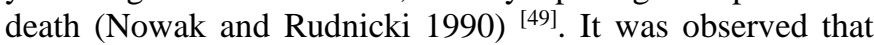
STS (silver thiosulphate) might be a powerful tool against the ethylene as this could increase the vase life of cut flowers (Reid and Nell 2000). It was also discovered that the main cause behind the minimizing of cut flower is the contamination of microbes (Kazemi et al., 2011) ${ }^{[34]}$. Various chemicals has been use in maximizing the vase life of cut flowers but effective treatment found was the pulse application of silver thiosulphate (Sexton et al., 1995; Ichimura and Hiraya, 1999 and Liao et al., 2000) [60, 30, 39]. Depending upon the plant species and the applied chemicals, various concentration has varied effect on postharvest life of cut flowers. Silver was found as an ethylene inhibitor and a germicide. Various studies has been on different chemicals and on different crops as it was stated that BA and GA $\mathrm{A}_{3}$ both maximize the vase life of chrysanthemum (Gue et al., 2004) [25]. Likewise, in rose, it was observed that the combination of 8-HQS and sucrose can increase the vase life (Elgimabi and Sliai, 2013) ${ }^{[22]}$.

\subsection{Harvesting stage and time}

The post harvest physiology of cut flowers can be affected by both stage and time of harvest. As stage and time of harvest have direct impact on post harvest storage and vase life of cut flowers. The improper stage and time of harvest affects the maximum postharvest potential of cut flowers Various factors like environmental conditions, the distance of market and the consumer's requirement are greatly varies with flowers. In general, cut spikes at early stage will ensure full opening and flower development with better vase quality. But in most cases, cut spikes should be preferred at bud stage, as because of this, flowers will be less susceptible to environmental conditions like high temperature (Halvey and Mayak, 1979). The genotype alone is not the reason behind the quality, appearance and longevity of cut flowers but there are various other factors like cultivation condition, right time to harvest and suitable postharvest handling will also affect. During the post harvest stages, the keeping quality of cut flowers is crucial in global market, where the items of floriculture is extremely competitive.

\subsection{Harvesting methods}

Usually the flowers for a longer time remains turgid if harvested at proper development stage. Flowers which are harvested at an advance stages, generally have shorter vase life. Usually for long distance transportation, the flowers are harvested at immature stage whereas at advance stage for local market. Moreover, the stage of harvest also differs with the purpose that for what purpose, we will use flower. Based 
on the purpose, the harvest stage of rose is defined by various scientists (Bhattacharjee, 1992; Gudin, 1992; De et al., 1996). In the two varieties of rose viz. Super star and Raktagandha, the post harvest life and quality of cut flowers are directly proportional to the stem length. However in Priyadarshini variety of rose, there are eight different stages of harvest and among all those, more life and diameter can be obtained when harvested at calyx and bud are at right angle and the unfurling of petals from the tip (Bhattacharjee, 1993). Whatever the purpose behind the harvesting stage of rose, the trend in reducing content of sugar of leaves and increasing the net reduction of sugar content of corolla from harvest towards the senescence which in vases (Bhattacharjee and Rajan, 2001).

\section{Post harvest technology}

The stage of the crop production just after harvest and it includes pre-cooling, grading, shorting, materials and methods of storage and some treatments which are done to increase the vase life of cut flowers.

\subsection{Pre-cooling}

Before storage or export of any commodity, it is necessary to remove field heat. The pre cooling temperature vary with the cultivar and species and the the optimum temperature for precooling for various crops viz. $1-3^{\circ} \mathrm{C}$ for rose, $4^{\circ} \mathrm{C}$ for gladiolus and gerbera and $1{ }^{\circ} \mathrm{C}$ for carnation. The respiration rate minimizes by pre-cooling and breaks down the stored material and nutrition which is stored in petals, leaves and stems. Moreover, it also inhibits the loss of water and also minimizes the sensitivity of flower to ethylene. In some species, it minimizes the height of plant, persuade the formation of flower bud and also minimizes the flower buds and side branches (Berghoef and Zevenbergen, 1990) ${ }^{[11]}$. Likewise, metabolisation of starch, fructose and sucrose also maximizes.

\subsection{Grading and sorting}

The flowers are discarded during grading, which are damaged or infected with some pest or disease. Based on the length of stem and size of bud, flowers are graded. The selected ones are bunched together in a bundle of 10,12 or 15 . The flowers judgement can be done through the length of the stem and the bloom of the flower. The grade of the flower varies with crop such as for rose, the flowers which have uniform color and stem length are bunched while for gladiolus, flowers are graded according to the floret number per spike and the length of spike (Staby et al., 1978).

\subsection{Pulsing treatment}

The solution of pulsing with sucrose have the well known ability to maximize the vase life and improves post harvest quality. Pulsing is the supplying a solution through stream of transpiration however pulsing term means placing the freshly harvested flowers for a relatively short period of time i.e. from seconds to few hours in a special formulated solution enhance the vase life of cut flowers (Post harvest management of horticultural crops). From the absence of sugar signals form some part of complicate array of exogenous and endogenous signals that regulates senescence (van Doorn,

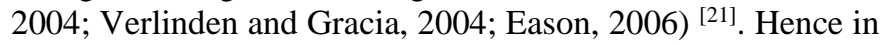
vase solutions, sugars solutions are preferred to extend the vase life as these solutions helps to improve relations of water and for maintaining the energy, provide cellular homeostasis. Instead of all these, this also helps in minimizing the responsiveness of ethylene and ultimately extends senescence in the cut flowers. Moreover, linking of cytokinin interpose extends senescence in plants to absence or presence of sugars (Eason, 2006; van Doorn and Woltering, 2008; Arrom and Munne-Bosch, 2012) ${ }^{[68]}$. Sucrose is best metabolized sugar among the majority of cut flowers and hence, this is preferred preservative solution. Besides this, other sugars like fructose, glucose, trehalose etc are found best in some flowers. As in gladiolus, trehalose has been found to be the best preservative solution (Yamada et al., 2003) ${ }^{[72]}$. In post harvest, pulsing solution containing sugar was found effective in most of the flowers.

\subsection{Respiration}

The respiration rate depends upon the amount of carbohydrate available in the flowers which was harvested, temperature and apply some chemicals to promote it. The rate of respiration is directly proportional to temperature and at higher amount they causes tissue burning. Hence the life of flowers is minimized (Krishisewa).

\subsection{Storage methods and materials}

Including the effect of the factors (both biotic and abiotic) that triggers the organs senescence, the life of cut flowers after harvest, is very daring process (Reid \& Jiang 2012). Storage and packaging are the two main factors in the post harvest life of flowers. To ensure fresh quality of flowers to the consumer, adequate packaging combined with pulsing is helpful. It was stated that after removed from the storage, the open flowers stems and buds recut and then placed into a solution of warm conditioning and then graded and bunched after several hours and then for refrigeration, return to the solutions before marketing (Basemer, 1980).

During the post harvest management of flowers, storage plays a crucial role and provides an opportunity for long term shipment of cut flowers. There are various methods by which storage can be done and the methods are cold storage (dry and wet cold storage), low pressure storage, controlled atmospheric storage, modified atmospheric storage etc.

- Cold storage: It is the one of the method of storage of cut flowers which enables to accumulate large quantities of cut flowers after harvesting. Moreover, treatment of low temperature during the period of shipment and storage, minimizes the entire tissue metabolism, slows down the rate of respiration. Harvesting of flowers should be done at optimum developmental stage and adequate floral preservative should be used for pre-treatment and for fast packaging, flowers are pre-cooled. Besides this, it is mandatory to maintain stable temperature and that temperature varies with the crop and based on the requirement, flowers can be stored in dry or wet conditions.

- Wet storage: In this, flowers with their bases dip in a vase solution for a short time. $3-4^{\circ} \mathrm{C}$ temperature slightly higher than the temperature used for dry storage, is used during wet storage. To avoid subsequent decay and wetting, the lower most leaves of the stem are removed. Sodium hypochlorite is used for the disinfection of water to avoid stem plugging which is used by infected vase water and bacteria, fungi or yeast may be the reason behind this.

- Dry storage: This method of storage is used for the long term storage of flowers. The harvesting of fresh flowers must be done in the morning and plastic sleeves/bags or boxes are used for grading and sealing to prohibit the loss of moisture. Prior to storage, pulsing of flowers are done with the preservative solutions containing sugars, anti 
ethylene and anti microbial compounds. To absorb condensed moisture which appears on the bloom, flowers must be wrapped in soft paper.

- Controlled atmospheric storage: This method of storage based on the principle of regulation of three parameters viz. carbon dioxide, temperature and oxygen. It maximizes the storage life by inhibiting the production and action of ethylene. Besides all the advantages, it has some disadvantages such as, it has high cost of application.

- Modified atmospheric storage: It is not much effective as compared to controlled atmospheric storage. The reduction in the $\mathrm{O}_{2}$ level and increase in $\mathrm{CO}_{2}$ level occurs due to tissue respiration because flowers are stored in sealed bags. The reduction in the biosynthesis level of ethylene occurs due to high level of $\mathrm{CO}_{2}$ and hence maximizes the longevity of flowers.

- Low pressure storage: It is also known as hypobaric storage. In this method, flowers are stored in low temperature, pressure and cooled moist air. Under low pressure, ethylene and $\mathrm{CO}_{2}$ like gaseous substances are formed from the stomata and intercellular spaces. At low levels of $\mathrm{O}_{2}$ and other volatile compounds, ethylene production is reduced and low pressure storage is attributed behind this.

\section{Use of various pulsing methods in different ornamentals crops}

The fresh flowers usually loose some of their quality while passing to the market after harvesting and the quality is affected to some extend that dissatisfies the consumer (Panhwar, 2006; Asfanani et al., 2008) [50, 7]. Cut flowers maintain their influence for a short period of time under normal conditions but most of the flower lovers wants to enjoy their natural beauty for a longer period of time which maintains the socioeconomic value (Tsegaw et al., 2011; Zamani et al., 2011) ${ }^{[66,75]}$. Although short vase life of cut flowers include wilting, production of ethylene and blockage of vascular tissues by air and microorganisms (Elgimabi, 2011) [42]. So, preservative solutions are found best to overcome from this problem and the preservative solutions generally required energy source which minimizes the build up of microbes, vascular blockage, maximizes stem water uptake and negative effect of ethylene becomes arrested (Nigussie, 2005) ${ }^{[48]}$. So, to prolong the vase life, various preservatives to the vase solutions are recommended (Ichimura et al., 2006) ${ }^{\text {[31] }}$. The use of pulsing with some preservative solutions are following below:

- Rose: Rose belong to the family Rosaceae under which more than 150 species and 1400 cultivars come (Elgimabi, 2011) ${ }^{\text {[42] }}$. As this family provides best material for agro-based industry, this is known for their high economic value specially in cosmetics and perfumery industry. Moreover, it also plays a crucial role in medicine and nutrition (Butt, 2003) ${ }^{[15]}$. Roses are also recognized as the queen of flowers but generally roses have short vase life (Gerailoo and Ghasemnezhad, 2011) [24]. The important germicide which is used in floral industry to extend the vase life is 8-hydroxyquinoline sulphate. Moreover, in various concentrations, sucrose is also used as preservative solution (Butt, 2005) ${ }^{[14]}$. But sucrose can not be used alone without any germicide as if it lowers the vase life. To make the effective treatment, sucrose must be added to HQS. Likewise, the beneficial floral preservative can be made by adding sugars with biocides (Abou El-Ghait et al., 2012). Instead of these two, various studies has been done to know the role of silver nitrate in extending the vase life of flowers. Silver nitrate minimizes the production of ethylene in plant tissuses. Moreover, it also provides the activity of antimicrobial inside the plant tissue. Pulsing with silver nitrate maximizes the vase life and uptake of solution in cut roses (Singh and Tiwari, 2002) ${ }^{[61]}$. However, silver nitrate with sucrose was found effective solution.

- Carnation: Carnation is known as the fourth important cut flower crop in the world. As like rose, it has most important role in florist trade as well as it act as a bedding plant in the garden (Ali et al., 2008). As like other cut flower species, post harvest senescence is the major limitation found in carnation flowers. Carnation is well known ethylene sensitive flower, so to minimize the binding capacity of ethylene, silver nitrate is found best but because of its heavy nature, it has some environmental effects, so can not use commercially (Nell, 1992) ${ }^{[45]}$. So, the non-toxic compound which is found effective to extend the vase life and storage life (Porat et al., 1995) [51] is 1-Methylcyclopropene and this compound is best alternative to silver thiosulphate. Although it is also stated that the use of ethanol can be helpful in maintaining the production of ethylene in cut flowers of carnation (Pun et al., 2001) ${ }^{[52]}$. As ethanol is a natural product so easy and safe to use.

- Gladiolus: Being a commercial grown crop, gladiolus is an important crop all over the world. It is also recognized as the queen of bulbous flower crop. Usually, gladiolus is known for its spikes and these spikes can stay up to 7-8 days under tap water (Singh et al., 2008) ${ }^{[63]}$. By adopting adequate post harvest technologies, the quantitative and qualitative loss can be minimized. So the economical method which is done to maximize the post harvest life is floral preservatives (Salunkhe et al., 1990) ${ }^{[57]}$. To promote the opening of flower and to enhance the vase life, pulsing is found to be an effective method. It is stated that the respiratory substrate that helps in maintaining the favourable water balance (Kumar and Deen, 2017) ${ }^{[38]}$. However, it was found that pulsing with sucrose solution results in enhanced vase life, spike length increases upto maximum and less drooping of florets.

\section{Effective storage materials in various commercial crops}

As mentioned above that storage and packaging of cut flowers plays a crucial role in post harvest handling of cut flowers, so there are various packaging material, before passive refrigeration, can be use for the managing the better quality of cut flowers. Although the combined effect of preservatives during packaging and storage methods can be helpful in extending the vase life of cut flowers. The effect of various packaging materials and storage methods are as follows:

- Rose: Roses are the one of the most important ornamental crop around the world. It is much loved by the people. It plays a crucial role in various occasions and especially during valentines day, as it is a symbol of love. Most of the people enjoy its beauty for a long time but due to its short vase life, they can not do. So to overcome from this problem, various post harvest methods should be done. To make a flower qualitative, it is must to handle it carefully after harvest. Bayleyegn et al., $2012^{\text {[1] }}$ found that the vase life of rose can be enhanced by 
combined effect of preservatives and storage methods. However, there are various packaging materials which can be use to pack the flowers and cardboard boxes are mostly used in euthopia. During storage and transportation, gel pack boxes can minimize the temperature to $3-4^{\circ} \mathrm{C}$ (Nell et al., 2001) ${ }^{[47]}$. And while roses are packed in gel boxes then it leads to enhancing the vase life of rose. However it was also stated that the polythene is preferred over other packaging materials (Ahmad, 1986) ${ }^{\text {[2] }}$. Stage of harvest is also important because the proper harvesting stage leads to the more vase life and the proper harvesting stage of rose is tight bud stage. From all the factors mentioned earlier, it is concluded that by proper post harvest handling, the vase life and beauty of roses can be extended and should be harvested at proper stage.

- Carnation: Because of the high economic importance, carnation flowers are most popular flowers in the world. People wants long attractiveness of ornamental plants and production life (Kader, 2003) ${ }^{[32]}$. Cut carnations has two forms viz. standard and spray, and standard carnations have a single flower on the stem whereas in spray types, multiple flowers are found. Among these types of carnations, spray types are mostly preferred because they have the capacity to meet the modern demand of consumer with minimum labour. There are various factors on which modern varieties of carnation are selected and the factors are length of stem, petal number, size of flower and especially the vase life of cut carnations (Satoh et al., 2005a) [59]. Behind the deterioration of flowers, dehydration is the main cause so to minimize this, temperature during storage must be maintained, as temperature is the main factor. The high and low temperature respond differently to the flower. It was observed that soon after harvest, by minimizing the temperature, rate of respiration and water loss are reduced and hence activity of microbes slows down and sensitivity to ethylene also is also minimized. While on exposing the flowers to high temperature, production of ethylene is delayed (Verlinden and Woodson 1998). Moreover at high temperature, blockage of ethylene production leads to the prohibition of biosynthesis enzymes activity in carnation flowers (Yangkhamman et al., 2005) ${ }^{[73]}$. However it is also stated that because of the prohibition of ACC synthase and ACC oxidase flower activities, depression of ethylene production can occur in cut flowers of carnation (Yangkhamman et al., 2007) ${ }^{[74]}$. It must be keep in mind that after harvesting the flowers, it should be cooled quickly. And the loss of water can be minimized by maintaining the humidity up to $95-98 \%$. But high humidity should be preferred with low storage temperature because the combination of high humidity with warm temperature favours the growth of bacteria and fungi. Besides this, the temperature required by carnation flowers for long dry storage varies from $0-1^{\circ} \mathrm{C}$ while the optimum temperature required for wet storage is $4^{\circ} \mathrm{C}$. At $1^{\circ} \mathrm{C}$, flowers are placed into a box with polythene and newspaper. As mentioned above that harvesting stage is most important for the postharvest life of flowers. So, it is stated that the flowers which are harvested at open stage, can be stored for 2-4 weeks whereas the flowers which are harvested at developmental early stages, can be stored up to 4 months. But the temperature should not be 0.5 , as it causes freezing injury to the flowers. Moreover, for minimizing the ethylene damage potential, it is must to keep proper sanitation in the storage area, even fruits or vegetables should be near to the storage area (Reid, 2004). Usually the carnations are packed in standard horizontal fireboard boxes. It is concluded that the standard carnations should be harvested at bud stage while the miniature carnations should be harvested at the stage when at least one flower per stem is open.

- Gladiolus: Among the cut flowers, it s a high grown crop and well known for delightful floret bearing spikes with varying size and forms with smooth ruffled and crinkled tepals (Singh, 2006). For the long shipment of flowers, it is must to follow the appropriate storage methods (Jain et al., 2006). Moreover the vase life of cut flowers can be maximized by the use of various packaging materials. The different types of packaging materials viz., news paper, butter paper, cellophane paper, plastic bags, CF Boxes, etc are helpful in slow opening of florets. Despite, it is also helpful in maximizing the $\mathrm{CO}_{2}$ production and minimizing the production of $\mathrm{O}_{2}$. The amount of ethylene can be reduced by minimizing the temperature and hence the storage life of gladiolus can be improved. During the periods of decline in demand, storage of flowers under refrigeration is an important process but it is observed that under refrigeration condition, gladiolus spikes can not be stored well and so, can be stored under controlled atmospheric storage. Besides all these, it is concluded that spikes wrapped with cellophane when stored at $40^{\circ} \mathrm{C}$, gives better results. So, the post harvest quality of spikes can be improved by wrapping with cellophane and storage for 7 days. And in combination with this, 12 hours pulsing is recommended.

\section{Innovative technologies to extend the vase life of cut flowers}

As mentioned above, there are various factors that affect the vase life of cut flowers and becomes a big problem in marketing of the floriculture crops. So it is necessary to take some steps to overcome from this loss. Besides this, there are some ethylene sensitive flowers such as carnation. For satisfying the consumer and to maintain the quality of the flowers, it is must to take steps against it. Because as like other parts of the plants, cut flowers are also an actively metabolizing organs and hence with time, they deteriorate (da Silva Vieira et al., 2014). Both the postharvest and production stages are influenced by some major factors viz. status of carbohydrate, water relation, pathogens and ethylene (Darras et al., 2005 and Dahal 2013) ${ }^{[18]}$. Various studies has been done and it was stated that vase life can be minimized by different vase solutions by minimizing the respiration rate and senescence (Kazemi et al., 2011) ${ }^{\text {[35]. }}$

Moreover, it is stated that the antimicrobial properties are known to be found in compost which is produced from the decaying organic matter and the humic substances that shields and plants can be nourished by various ways (de Bertoldi 2010 and Steel et al., 2018). Stability of compost also defined as the prohibition of degradation from compost organic matter plays an important rule because of oxygen or nitrogen depletion and the immature compost due to phytotoxic compounds (Raviv, 2005). It is suggested that synthetic chemical preservative solutions can be potentially substituted by mature and the stable compost mixed tea with other additives which are natural. Because of environment friendly and antimicrobial properties, it has been stated that the various natural products like essential oils, lemon juice and 
other fruit extracts could also be helpful in enhancing the vase life of cut flowers (Mehraj et al., 2013 and El-Moneim et al., 2018).

Post harvest life of various horticultural crops including flowers can also be maximizes by nitric oxide. In plants, it was first time characterised in 1996 (Leshem and Haramaty, 1996) and consequential linked investigated occurrence to different physiological processes such as modulation of endogenous ethylene etc. Various post harvest application of nitric oxide has been found effective in various flower crops and other horticultural commodities also when applied as a short term treatment of fumigation at low concentrations (Wills et al., 2000).

Further more studies has been done on the compounds that can extend the vase life of cut flowers and essential oil was found effective as essential oils are environment friendly natural product of plant and have antimicrobial properties against the pathogens (Bayat et al., 2013) ${ }^{[9]}$. With the use of essential oils in various industries including pharmaceutical and other chemical industries, the demand of essentials oils increasing worldwide. And without any doubt, all the demand is due to its properties and environmental friendly nature. It was stated that the factors which are needed to extend the vase life of cut flowers viz. uptake of water etc, are also found in essential oils. It was found that the thyme oil is helpful in extending the vase life of cut flowers. Thyme is an aromatic perennial evergreen herb belong to the family Lamiaceae (wikipedia). Consequently the positive impact of thyme oil was seen in various flowers like gerbera (Amini et al., 2014 and Dareini et al., 2014) ${ }^{[4,17]}$, chrysanthemum (Bazaz et al., 2015) ${ }^{[10]}$ and narcissus etc. Including thyme oil, it aws also stated that the other essential oils such as lavender, savory, ajowan are also helpful in extending the vase life of carnation because of the biodegradable natural extracts (Kazemi and Ameri, 2012) ${ }^{[33]}$. Besides all these essential oils, there are other more types of essential oils such as geranium oil etc., which are found effective in extending the vase life of cut flowers.

Moreover it was also concluded that the nanotechnology is also useful in prolonging the vase life of flowers. The nanotechnology has a positive impact on cut flowers vase life. $\mathrm{AgNO}_{3}$ is act as ethylene blocker and antimicrobial factor in plants, as it relatively unmobile. The use of Nanosilver components with pulse solution or vase solution is new (Solgi et al., 2009) [65] and it also has some antibacterial agent (Morones et al., 2005) ${ }^{\text {[43] }}$. So by the use of nano-particles, bacterial growth can be minimized and hence increasing the vase life of cut flowers. Its positive impact was seen in various cut flower crops such as gladiolus, gerbera and rose (Hassan et al. 2014). Besides all these advantages, it has also some limitations as it is not environment friendly because of its heavy nature.

\section{References}

1. Bayleyegn Tesfaye B, Workneh TS. Effects of pulsing solution, packaging material and passive refrigeration storage system on vase life and quality of cut rose flowers. African Journal of Biotechnology 2012;11(16):3800-3809.

2. Ahmad M. Effect of different packing materials and chemicals on post-harvest life of chrysanthemum flowers. M.Sc. Thesis. Univ. of Agric., Faisalabad, Pakistan, 1986.
3. Ali A, Afrasiab H, Naz S, Rauf M, Iqbal J. An efficient protocol for In vitro propagation of carnation (Dianthus caryophyllus). Pak. J Bot 2008;1:111-121.

4. Amini S, Jafarpour M, Asgari K. Effect of temporary and permanent treatments of extracts of thyme and stevia on postharvest quality of Gerbera cut flowers. Abstract of Emerging Trends in Scientific Research 2014;1(16):58564.

5. Anjana Sisodia, Priyanka Kumawat, Minakshi Padhi, Anil Singh K. Effect of Packaging Materials and Temperature on Post-harvest Life of Gladiolus cv. Punjab Dawn. International Journal of Current Microbiology and Applied Sciences 2018;7(8):889-893.

6. Arrom L, Munne-Bosch S. Sucrose accelerates flower opening and delays senescence through a hormonal effect in cut lily flowers. Plant science 2012;188-189:41-47.

7. Asfanani M, Davarynejad G, Tehranifar A. Effects of Pre-harvest Calcium Fertilization on Vase Life of Rose cut Flowers cv. Alexander, Ferdowsi University of Mashhad, Iran 2008.

8. Asghar Ebrahimzadeh, Silvia Jimenez, Jaime A Teixeira da Silva, Shigeru Satoh, Maria Teresa Lao. Postharvest Physiology of Cut Carnation Flowers. Global Science Books 2008;2(2):56-71.

9. Bayat H, Geimadil R, Saadabad AA. Treatment with essential oils extends the vase life of cut flowers of lisianthus (Eustoma grandiflorum). J Med Plants By-prod 2013;2:163-169.

10. Bazaz AM, Tehranifar A, Karizaki AR. Use of ethanol, methanol and essential oils to improve vase-life of chrysanthemum cut flowers. Int Res J Appl Basic Sci 2015;9(8):1431-36.

11. Berghoef J, Zevenbergen AP. The effect of precooling environmental factor and growth regulating substances on plant height of Freesia as a pot plant. Acta Horti 1990;266:251-257.

12. Bhattacharjee SK. Post harvest management of cut flowers, cut foliage and postharvest management of potted plant. J Orna Hort New Series 1999;2:32-39.

13. Bhawana Lama, Mitali Ghosal, Saran Kumar Gupta, Palash Mandal. Assessment of Different Preservative Solutions on Vase Life of Cut Roses. Plant Physiology and Pharmacognosy Research Laboratory www.jornamental.com. 2251-6433.

14. Butt SJ. A Review on prolonging the vase life Roses. Pakistan Rose Annual. Published by Pakistan National Rose Society 2003, 49-53.

15. Butt SJ. Extending the vase life of roses (Rosa hybirida) with different preservatives. Int. J Agricul. Biology 2005;7:91-99.

16. Celikel FG, Dodge LL, Reid MS. Efficacy of 1-MCP and Promalin for extending the post-harvest life of oriental lilies (Lilium X 'Mona Lisa' and 'Stargazer'). Scientia Horticulturae 2002;93:149-155.

17. Dareini H, Abdos V, Danaee E. Effect of some essential oils on postharvest quality and vase life of Gerbera cut flowers. Eur J Exp Biol 2014;4(3):276-280.

18. Darras AI, Terry LA, Joyce DC. Methyl jasmonate vapour treatment suppresses specking caused by Botrytis cinerea on cut Freesia hybrida L. flowers, Postharvest Biology and Technology 2005;38(2):175-182.

19. Da Silva JAT. The cut flower: postharvest considerations. J Biol. Sci 2003;3(4):406-442.

20. Eason JR, Ryan DJ, Pinkney TT, O’Donoghue EM. Programmed cell death during flower senescence: 
Isolation and characterization of cysteine proteases from Sandersonia aurantiaca. Funct. Plant Bio 2002;1(29):1055-1064.

21. Eason. Molecular and genetic aspect of flower senescence. Steward Postharvest Review 2006;2:1-7.

22. Elgimabi MN, Sliai AM. Effect of preservative solutions on vase life and postharvest qualities of rose cut flowers (Rosa damascene cv. Trigintipetala). American-Eurasin J Agric. \& Environ 2013;13(1):72-80.

23. Ferrante AA, Mensuali-Sodi, Serra G, Tognoni F. Evaluation of postproduction performance of Salvia splendens potted plants for interiors use. Acta Hort 2006;723:415-419.

24. Gerailoo S, Ghasemnezhad M. Effect of salicylic acid on antioxidant enzyme activity and petal senescence in 'Yellow Island' cut rose flowers. Journal of Fruit and Ornamental Plant Research 2011;19(1):183-193.

25. Gue WM, Zheng L, Zhang ZH, Zeng WQ. Photohormones regulate senescence of cut chrysanthemum. Acta Horticulture 2004;6(24):349-353.

26. Hailay Gebremedhin, Bizuayehu Tesfaye, Ali Mohammed, Dargie Tsegay. Influence of preservative solutions on vase life and postharvest characteristics of rose (Rosa hybrid) cut flowers. International Journal for Biotechnology and Molecular Biology Research 2013;4(8):111-118.

27. Halevy AH, Mayak S. Senescence and post-harvest physiology of cut flowers. Part I Hort. Rev (ed. Janick, J) 1979;1:204-236.

28. Hussen S, Yassin H. Review on the impact of different vase solutions on the postharvest life of rose flower. International Journal of Agricultural Research and Review 2013;1(2):13-17.

29. Hunter D, Steele BC, Reid MS. Identification of genes associated with perianthe senescence in Daffodil (Narcissus pseudonacissus L. Dutch Master). Plant Sci 2002;163:13-21.

30. Ichimura K, Hiraya T. Effect of silver thiosulphate complex (STS) in combination with sucrose on the vase life of cut sweet pea flowers. J Japan Soc. Hort Sci 1999;68:23-27.

31. Ichimura K, Taguch M, Norikoshi R. Extension of the vase life in cut roses by treatment with glucose, isothiazolinonic germicide, citric acid and aluminum sulphate solution. J Agri. Resear 2006;40:263-269.

32. Kader A. A perspective on postharvest horticulture. Hort Science 2003;38:1004-1009.

33. Kazemi M, Ameri A. Response of vase-life carnation cut flower to salicylic acid, silver nano particles, glutamine and essential oil. Asian J Anim Sci 2012;6(3):122-131.

34. Kazemi M, Zamani S, Aran M. Effect of some treatment chemicals on keeping quality and vase-life of gebrera cut flowers. Am J Plant Physiol 2011;6(2):99-105.

35. Kazemi M, Zamani S, Aran M. Effect of some treatment chemicals on keeping quality and vase-life of gebrera cut flowers. Am J Plant Physiol 2011;6(2):99-105.

36. Ketsa S, Piyasaengthong Y, Prathuangwong S. Mode of action of $\mathrm{AgNo}_{3}$ in maximizing vase life of Dendrobium Pompadour flowers. Postharvest Biology and Technology 1995;5:109-117.

37. Kumar N, Dubey RK, Misra RL, Misra S. Pre and Postharvest factors influencing cut flower longevity. In: Floriculture Research Trend in India. Indian Society of Ornamental Horticulture 2002, 1-12.
38. Kumar A, Deen B. Effect of ecofriendly vase solution on maximum buds opening and longer vase-life of tuberose (Polianthes tuberosa L.) cv. Hydrabad Duble. Journal of Pharmacognosy and Phytochemistry 2017;6(4):12331236.

39. Liao L, Lin Y, Huang K, Chen W, Cheng Y. Postharvest life of cut rose flowers as affected by silver thiosulfate and sucrose. Bot. Bull. Acad. Sin 2000;41:299-303.

40. Mahmoud I, Yagia Mohy Eldeenb, Elgemaby NE. Effect of Bactericides and Sucrose Pulsing on Longevity and Vase Life of Rose Cut Flowers. International Journal of Sciences: Basic and Applied Research 2005, 2307-4531.

41. Mahsa Ashouri Vajari, Ayoub Molaahmad Nalousi. Effect of Nitric Oxide on Postharvest Quality and Vase Life of Cut Carnation Flower. Journal of Ornamental Plants (Journal of Ornamental and Horticultural Plants) 2013;3(3):183-190.

42. Mohy Eldeen Nour Eldaim Elgimabi. Vase Life Extension of Rose Cut Flowers (Rosa Hybirida) as Influenced by Silver Nitrate and Sucrose Pulsing. American Journal of Agricultural and Biological Sciences 2011;6(1):128-133.

43. Morones JR, Elechiguerra JL, Camacho A, Holt K, Kouri JB, Ramirez TJ et al. The bactericidal effect of silver nano-particles. Nanotechnology 2005;16:2346-2353.

44. Mortensen ML, Fjeld T. Effects of air humidity, lighting period and lamp typeon growth and vase life of roses. Scientia Horticulturae 1998;73:229-237.

45. Nell TA. Taking silver safely out of the longevity picture. Grower talks 1992;6:35-38.

46. Nichols R. Ethylene production during senescence of flowers. J Hortic. Sci 1966;41:279-290.

47. Nell TA, Suzuki A, Leonard RT, Barrett LE, Clark D. Developing protocols for cut flowers longevity. Univ. of Florida, USA 2001;56:9799.

48. Nigussie K. Ornamental horticulture: A technical material. Jimma University College of Agriculture and Veternary medicine, 2005.

49. Nowak J, Rudniki RM. Postharvest handling and storage of cut flowers, florist green and potted plants. Timber Press, 1990.

50. Panhwar F. Postharvest technology of fruits and vegetables. ECO Services International, Hyderabad Sindh 2006.

51. Porat R, Shlomo E, Serek M, Sisler EC, Borochov A. 1Methylcyclopropene inhibits ethylene action in cut phlox flowers. Postharvest Biol. Technol 1995;6:313-319.

52. Pun UK, Rowrath JS, Barens MF, Heyes JA. The role of ethanol or acetaldehyde in the biosynthesis of ethylene in carnation (Dianthus caryophyllus L.). Post harvest biology and technology 2001;21:235-239.

53. Reddy BS, Singh K, Singh A. Effect of sucrose, citric acid and 8-hydroxyquinoline sulphate on the postharvest physiology of tuberose cv. Single. Advances in Agricultural-Research-in-India 1995;3(10):161-167.

54. Reid SM, Nell AT. Flower and plant care. This book has been published in society of American Florists (SAF) 2000.

55. Reid MS. Products facts: carnations, miniature carnations recommendations for maintaining postharvest quality. Bulletin of Postharvest Technology Research \& Information Center, 2004.

56. Sachi Gupta, Ashok Kumar. Effect of Different Levels of Pulsing Concentrations on Vase Life of Gladiolus (Gladiolus grandiflorus L.). International Journal of 
Current Microbiology and Applied Sciences 2018;7(9):330-334.

57. Salunkhe DK, Bhat NR, Desai BB. Post-harvest biotechnology of flowers and ornamental plants. Springer-Verlag, Berlin 1990, 349-412.

58. Satish Chand, Pankaj Panwar, Annand Rawat S, Ranjan Srivastava, Bhuj BD, Rajat Sharma. Effect of pulsing, packaging and storage on enhancing postharvest quality of gladiolus cv white prosperity. International Journal of Chemical Studies 2019;7(3):3148-3151.

59. Satoh S, Nukui H, Inokuma T. A method for determining the vase life of cut spray carnation flowers. Journal of Applied Horticulture 2005a;7:8-10.

60. Sexton R, Porter AE, Littlejohns S, Thain DS. Effects of diazocyclopentadiene (DACP) and silver thiosulfate (STS) on ethylene regulated abscission of s weet pea flowers (Lathyrus odoratus L.). Ann Bot 1995;75:337342.

61. Singh AK, Tiwari AK. Effect of pulsing on postharvest life of Rose V. Doris Tystermann. South-Indian-Hort 2002;50:140-144.

62. Singh AK. Flower Crops: Cultivation and Management, New India Publishing Agency 2006, 447.

63. Singh A, Kumar J, Kumar P. Effect of plant growth regulators and sucrose on post-harvest physiology, membrane stability and vase life of cut spikes of gladiolus. Plant Growth Regulator 2008;55:221-229.

64. Singh Kushal, Kumar Gunjeet, Saha TN, Kumar Ramesh. Post Harvest Technology of Cut Flowers, 2013, 26-28.

65. Solgi M, Kafi M, Sadat Taghavi T, Naderi R. Essential oils and silver nano-particles (SNP) as novel agents to extend vase life of gerbera (Gerbera jamesonii cv. 'Dune') flowers. Postharvest Biol. Technol 2009;53:155158.

66. Tsegaw T, Tilahun S, Humphries G. Influence of pulsing biocides and preservative solution treatment on the vase life of cut rose (Rosa hybrid L.) varieties. J Appl. Sci. Technol 2011;2(2):1-18.

67. Van Dooran WG. Is petal senescence due to sugar starvation. Plant Physiology 2004;134:35-42.

68. Van Dooran WG, Woltering EJ. Physiology and molecular biology of petal senescence. J Exp. Bot. 2008;53(3):453-480.

69. Verlinden S, Gracia JJV. Sucrose loading decreases ethylene responsiveness in carnation (Dianthus caryophyllus cv. White sim) petals. Post harvest Biology and Technology 2004;31:305-312.

70. Verlinden S, Woodson WR. The physiological and molecular responses of carnation flowers to high temperature. Postharvest Biology and Technology 1998;1:185-192.

71. Waters WE. Relationship of water salinity and fluorides to keeping quality of chrysanthemum and gladiolus cut flowers. Proceedings of American Society of Horticultural Science 1968;92:633-640.

72. Yamada T, Takatsu Y, Manabe T, Kasumi M, Marubashi W. Suppressive effect of trehalose on apoptotic cell death leading to petal senescence in ethylene- insensitive flowers of gladiolus. Plant Science 2003;164:213-221.

73. Yangkhamman P, Fukai S, Ichimura K. Ethylene production and vase life of cut carnation flowers under high temperature conditions. Journal of the Japanese Society for Horticultural Science 2005;74:337-341.

74. Yangkhamman $\mathrm{P}$, Tanase $\mathrm{K}$, Ichimura K, Fukai S. Depression of enzyme activities and gene expression of
ACC synthase and ACC oxidase in cut carnation flowers under high-temperature conditions. Plant Growth Regulation 2007;53:155-162.

75. Zamani S, Kazemi M, Aran M. Postharvest life of cut rose flowers as affected by salicylic acid and glutamin. World Appl. Sci 2011;12(9):1621-1624.

76. Zeltzer S, Meir S, Mayak S. Modified atmosphere packaging (MAP) for long-term shipment of cut flowers. Acta Horticulture 2001;553(2):631-634. 